\title{
Mathematical modeling of the process of iron removal in a biological reactor by bacteria Gallionella and Leptothrix
}

https://doi.org/10.31713/MCIT.2020.07

\author{
Igor Prysiazhniuk \\ dept. of Hanging Mathematics \\ Rivne State University of Humanities \\ Rivne, Ukraine \\ igorpri79@gmail.com
}

\author{
Alexander Kvartenko \\ dept. of Water Supply, Water Sewerage and Drilling \\ National University of Water and Environmental Engineering \\ Rivne, Ukraine \\ o.m.kvartenko@nuwm.edu.ua
}

\author{
Olena Prysiazhniuk \\ dept. of Automation, Electrical Engineering and Computer-Integrated Technologies \\ National University of Water and Environmental Engineering \\ Rivne, Ukraine \\ o.v.prysiazhniuk@nuwm.edu.ua
}

\begin{abstract}
This paper proposes a mathematical model for computer prediction of the process of iron removal of groundwater in a bioreactor, taking into account the presence of two species of iron bacteria Leptothrix and Gallionella in groundwater while maintaining a constant filtration rate. An algorithm for a numerical-analytical method for solving the corresponding nonlinear boundary value problem for an inhomogeneous system of differential equations in partial derivatives of the first order has been developed. The developed model allows using computer experiments to predict the change in time on the depth of contact loading of cleaning efficiency, distribution of bacterial biomass values in both filtered water and in filter loading, mass of stationary and mobile matrix structures. Also, the proposed model allows to predict the duration of effective operation of the biological reactor of iron removal between its washing.
\end{abstract}

Keywords - mathematical model, computer prediction, the process of removing iron from groundwater, impurity, adsorption, kinetic model of biological iron removal, matrix structures, method of characteristics

\section{INTRODUCTION}

In the preparation of water there are three groups of removal of iron compounds from it: reagent-free, reagent and biological [1]. Analysis of theoretical research and experimental data of domestic and foreign scientists and engineers indicates significant advantages of the biological method over traditional physico-chemical methods of groundwater iron removal in the treatment of weakly acidic and near-neutral waters with low and medium alkaline reserve $[2,3]$. In particular, in the biological method, the rate of oxidation of iron compounds both in mineral form and in the form of organic complexes is accelerated several times [2, 4]. An urgent task today is the transfer of existing stations of simplified aeration - filtration, to work by the method of biochemical oxidation [2]. Indeed, the reagent-free method of simplified aeration - filtration is the most common, but with increased anthropogenic load on water supply sources and in case of deterioration of natural water quality parameters, this method has a relatively narrow range of applications [1].

The biochemical method of groundwater iron removal has become quite common in recent decades in many countries around the world [3]. Thus, in [6] the dominance of the biological method of groundwater iron removal over the physicochemical method in the case of weakly acidic and nearneutral waters with medium and low alkaline reserve is substantiated. Extensive practical use of biological iron removal technology of groundwater made it possible to obtain experimental data [2, 5], which gave a new impetus to theoretical research in this area. Therefore, a very important issue today is the study of biological reactors in different conditions of their operation, as well as the development of appropriate mathematical models of these processes.

Known today mathematical models of groundwater treatment from iron are divided into several groups according to the degree of consideration of various factors and processes. Models that take into account only the oxidation kinetics of $\mathrm{Fe} 2+$ belong to the first group. The first models of this type are proposed in [7-9], they are usually two-component. In [7], it was confirmed that the oxidation rate of $\mathrm{Fe} 2+$ ions in bicarbonate solutions primarily depends on both the concentration of $\mathrm{Fe} 2+$ ions and the $\mathrm{pH}$ value. A known model for the removal of iron compounds from water is presented in [10] and describes the operation of treatment plants only at the initial stage of the filtration cycle. This model belongs to the second type. 


\section{Modeling, control and information technologies $-\mathbf{2 0 2 0}$}

The most complex are multi-component models that take into account most of the existing processes of iron removal of groundwater. In particular, they include the model proposed in [11]. It takes into account the influence of mass transfer processes, kinetics of various transformations and exchange that occur in liquid and solid phases of the system relative to iron ions, oxygen, various forms of iron hydroxide and describes the process of water purification on fast filters at constant values of filtration velocities.

The results of theoretical studies of the process of accumulation of iron compounds on the loading of a two-layer filter during the iron removal of groundwater are given in [12]. The corresponding model consists of two blocks. The first, hydrodynamic unit contains the equations of filtration and continuity of the filtration flow, taking into account changes in the hydraulic characteristics of the filter. The second is the block of dynamics of iron compounds, which contains the equation of material balance with respect to the concentrations of iron $\mathrm{Fe} 2+$ and iron hydroxide $\mathrm{Fe}(\mathrm{OH}) 3$ both in solution and in solid phases.

In [13-15], the classical method based on the physicochemical mechanism of their extraction in the filtration process was used to extract $\mathrm{Fe} 2+$ cations from neutral waters. The biological factor that significantly affects the relevant processes in the treatment of weakly acidic and near-neutral groundwater was not taken into account. The works [13] [1617] are devoted to research of influence of the specified factor.

In [18] during developing a mathematical model of groundwater iron removal, the influence of biomass and matrix structures fixed on the reactor load on the purification processes was taken into account, and the factors of attachment-separation of bacteria and matrix under the action of flow hydrodynamics forces were taken into account. However, these models do not take into account the presence of iron bacteria of different species, the comfortable reproduction of which is significantly affected by various additional impurities, which does not give a complete picture of the bioreactor between washes.

\section{MATHEMATICAL MODEL}

For groundwater with low values of bicarbonate alkalinity $\left(<2.0 \mathrm{mmol} / \mathrm{dm}^{3}\right)$ the use of simplified aeration - filtration for iron removal is impractical, as it is impossible to remove aggressive carbon dioxide [19], as in the case of humic acids in water. According to [20-21], the biochemical method of removing iron compounds is effective in weakly acidic and near neutral groundwater at redox potential values from $-100 \mathrm{mV}$ to $300 \mathrm{mV}$ at $\mathrm{pH} 7.5$ and from $100 \mathrm{mV}$ to $400 \mathrm{mV}$ at $\mathrm{pH} 5,5$ [20], in the case of small concentrations of dissolved oxygen in water. For faster growth of iron bacteria of the genus Gallionella, dissolved carbon dioxide is used as an impurity, and for iron bacteria of the genus Leptothrix, organic compounds dissolved in water are used.
Consider the process of iron removal from weakly acidic groundwater with a permanganate oxidation value greater than $5,0 \mathrm{mg} \mathrm{O} / \mathrm{dm}^{3}$ on the bioreactor between its washes with existing bacteria of the genus Gallionella and Leptothrix. After the next flushing of the bioreactor, bacteria from the previous cycle and bacteria coming from the well with the flushing water remain in its loading. This provides the constant presence of bacteria in the bioreactor in the amount of 103-105 cells $/ \mathrm{sm}^{3}$ after its washing, which in turn provides the efficient operation of the bioreactor immediately after washing. The bacteria of the Leptothrix type that are present in the water from the wells, as a result of their vital activity, form porous covers-nanotubes of the same diameter, the bacteria of the Gallionella type bacteria form spiral structures. A porous structure of $\gamma-\mathrm{FeOOH}$ biominerals is formed from the covers of iron bacteria in the interporous space of the bioreactor loading [22, 23]. Gradually, this porous structure fills the entire interporous space of the contact load, convectively passing through the flow of water. Shells formed by Leptothrix bacteria and spiral covers formed by Gallionella bacteria are a kind of polymer matrix structure of biominerals. Bacteria that come from groundwater and multiply intensively are immobilized on this structure of biominerals. In turn, they form new matrix structures. Each new portion of water brings dissolved compounds of iron, carbon, oxygen, organic impurities, creating comfortable conditions for the activity of iron bacteria. Increasing the volume of the matrix in the interporous space of the bioreactor leads to its gradual migration to the lower layers of the load.

The described process of groundwater purification from iron compounds in a biological reactor is modeled by the following problem:

$$
\begin{gathered}
v=-\theta(M) g r a d P \\
\sigma(M) \frac{\partial B_{G}}{\partial t}=W_{G}(x, t) B_{G}-v(x) \frac{\partial B_{G}}{\partial x}-\gamma H_{G}(x, t)-\chi B_{G} \\
\sigma(M) \frac{\partial B_{L}}{\partial t}=W_{L}(x, t) B_{L}-v(x) \frac{\partial B_{L}}{\partial x}-\gamma H_{L}(x, t)-\chi B_{L} \\
\frac{\partial G}{\partial t}=W_{G}(x, t) G+\gamma(x, t) \cdot H_{G}(x, t)-\chi G \\
\frac{\partial L}{\partial t}=W_{l}(x, t) L+\gamma(x, t) \cdot H_{L}(x, t)-\chi L \\
\sigma(M) C_{t}=-v(x) \cdot C_{x}-\alpha_{1} W_{G}(x, t) B_{G}-\alpha_{1} W_{G}(x, t) G \\
\sigma(M) N_{t}=-v(x) \cdot N_{x}-\alpha_{2} W_{L}(x, t) B_{L}-\alpha_{2} W_{L}(x, t) L \\
\sigma(M) \frac{\partial F}{\partial t}=-v(x) \frac{\partial F}{\partial x}-\beta_{1} W_{G}(x, t)\left(B_{G}+G\right)- \\
-\beta_{2} W_{L}(x, t)\left(B_{L}+L\right) \\
\sigma(M) \frac{\partial S}{\partial t}=-v(x) \frac{\partial S}{\partial x}-k_{1} S+H^{*}(x, t)+ \\
+\eta_{1} W_{G}(x, t) \mathrm{B}_{G}+\eta_{2} W_{L}(x, t) \mathrm{B}_{L}
\end{gathered}
$$




\section{Modeling, control and information technologies $\mathbf{- 2 0 2 0}$}

$$
\begin{gathered}
\frac{\partial M}{\partial t}=k_{1} S-H^{*}(x, t)+\eta_{1} W_{G}(x, t) G+\eta_{2} W_{L}(x, t) L, \\
W_{G}(x, t)=\frac{\mu_{\max }^{G} \cdot F \cdot C}{\left(F+K_{F}\right) \cdot\left(C+K_{C}\right)}, \\
W_{L}(x, t)=\frac{\mu_{\max }^{L} \cdot F \cdot N}{\left(F+K_{F}\right) \cdot\left(N+K_{N}\right)} \\
H_{L}(x, t)=\left\{\begin{array}{l}
B_{L}, \text { if } B_{L}<B^{* *}-(L+G), \\
B^{* *}-(L+G), \text { if } B_{L} \geq B^{* *}-(L+G),
\end{array}\right. \\
H_{G}(x, t)=\left\{\begin{array}{l}
B_{G}, \text { if } B_{G}<B^{* *}-(L+G), \\
B^{* *}-(L+G), \text { if } B_{G} \geq B^{* *}-(L+G),
\end{array}\right. \\
H^{*}(x, t)=\left\{\begin{array}{l}
k_{2} \cdot M(x, t), \text { if } M(x, t)<M_{*}^{*}, \\
k_{3} \cdot\left(M(x, t)-M_{*}^{*}\right), \text { if } M(x, t) \geq M_{*}^{*},
\end{array}\right.
\end{gathered}
$$

where $x \in(0, l), l-$ the height of the working part of the biological reactor, $t \in(0, T), T$ - the time of effective operation of the treatment plant, which is obtained during the solution of the problem, it is equal to the time at which the maximum dirt saturation of the bioreactor is achieved, $M_{*}^{*}-$ maximum dirt capacity (maximum concentration of the matrix in the bioreactor), $S(x, t)$ - the concentration of matrix structures at point $x$ of the reactor at a given time $t$, which are in the flow of water passing through the bioreactor, $M(x, t)-$ the concentration of matrix structures fixed in the interporous space on the loading of the bioreactor, $B_{G}(x, t)$ and $B_{L}(x, t)$ mass concentrations of iron bacteria of the genus Gallionella and Leptothrix, respectively, in the water passing through the loading of the treatment plant, $G(x, t)$ and $L(x, t)$ - mass concentrations of iron bacteria of the genus Gallionella and Leptothrix, respectively, immobilized on the surface of the primary stationary shell of the contact load and matrix structures in the interporous space, $C(x, t)$ - the concentration of an additional source of inorganic carbon, $N(x, t)$ - the concentration of an additional source of organic compounds dissolved in water, $B^{* *}$ - the limit value of bacterial biomass in the matrix structures of the bioreactor, $\mu_{\max }^{G}, \mu_{\max }^{L}-$ the maximum specific growth rate of iron bacteria of the genus Gallionella and Leptothrix respectively, $F(x, t)-$ the concentration of ferrous iron in the source water, functions $W_{G}(x, t)$ and $W_{L}(x, t)$ describe the growth rate of microorganisms of the corresponding genera according to the Mono equation, $K_{F}, K_{C}, K_{N}-$ corresponding saturation constants, functions $H_{G}(x, t), H_{L}(x, t)$ establish the relationship between bacterial biomass per unit volume of source water passing through the filter and the average biomass of bacteria fixed on the surface of the contact loading grains and matrix structures in the interporous space, ensure the transition of bacteria from dynamic to stationary taking into account the maximum saturation of bacteria, function $H^{*}(x, t)$ describes the transition of matrix structures from steady state (stationary) to dynamic (mobile) taking into account the limiting saturation of the matrix, $P$ - hydraulic pressure in the bioreactor, $\theta(M)-$ filtration coefficient, $\sigma(M)$ - the porosity of the media, $v(x)$ - the velocity of water passing through the bioreactor, $\gamma=\gamma(x, t)-$ the function of iron bacteria immobilization velocity on matrix structures and on contact loading, $k_{1}-$ the coefficient that characterizing the share of matrix structures that pass from the dynamic state to the steady state, $k_{2}$ - the coefficient that characterizing the share of matrix structures that pass from the steady state to the dynamic state, $k_{3}$ - the coefficient that characterizing the proportion of the separation of the excess matrix structures, $\chi$ - the coefficient that characterizes the rate of bacterial death, $\alpha_{1}, \alpha_{2}$ - coefficients of the mass fraction of inorganic carbon and organic compounds those required for the construction of $1 \mathrm{~g}$ of cellular biomass of iron bacteria of the genus Gallionella and Leptothrix, respectively, $\beta_{1}, \beta_{2}$ - coefficients of mass fraction of $\mathrm{Fe} 2+$ ions, which are required for the construction of $1 \mathrm{~g}$ of cellular biomass of iron bacteria of the genus Gallionella and Leptothrix, $\eta_{1}, \eta_{2}$-mass fraction of $\mathrm{Fe} 3+$, in the form of biominerals $(\mathrm{FeOOH})$, which is formed during the construction of $1 \mathrm{~g}$ of biomass by bacteria fixed on stationary matrices in the interporous space of contact loading and bacteria in the flow respectively.

The initial and boundary conditions for problem (1) - (10) are next:

$$
\begin{gathered}
B_{G} x,\left.t\right|_{t=0}=\mathrm{B}_{G}^{0} x ; B_{L} x,\left.t\right|_{t=0}=\mathrm{B}_{L}^{0} x ; \\
C x,\left.t\right|_{t=0}=C^{0} x ; N x,\left.t\right|_{t=0}=N^{0} x ; \\
F x,\left.t\right|_{t=0}=F^{0} x ; S x,\left.t\right|_{t=0}=S^{0} x ; \\
B_{G} x,\left.t\right|_{x=0}=\mathrm{B}_{G}^{*} t ; B_{L} x,\left.t\right|_{x=0}=\mathrm{B}_{L}^{*} t ; \\
G x,\left.t\right|_{x=0}=G^{*} t ; L x,\left.t\right|_{x=0}=L^{*} t ; \\
C x,\left.t\right|_{x=0}=C^{*} t ; N x,\left.t\right|_{x=0}=N^{*} t ; \\
M x,\left.t\right|_{x=0}=M^{*} t ; S x,\left.t\right|_{x=0}=S^{*} t ;
\end{gathered}
$$

where $\mathrm{B}_{G}{ }^{0} x$ and $\mathrm{B}_{G}{ }^{*} x, \mathrm{~B}_{L}{ }^{0} x$ and $\mathrm{B}_{L}{ }^{*} x, C^{0} x$ and $C^{*} x, N^{0} x$ and $N^{*} x, F^{0} x$ and $F^{*} x, S^{0} x$ and $S^{*} x$ fairly smooth functions that are consistent with each other at the point $(0,0)$.

\section{PROBLEM SOLVING AND CONCLUSIONS}

Similarly to [24], the solving of the model problem (2) - (10) is reduced to the solving of $\mathrm{n}$ simpler problems, respectively, on the time intervals $n \Delta t<t<(\mathrm{n}+1) \Delta t$, where the choice of the value of $\Delta t$ is finally determined in the process of solving 


\section{Modeling, control and information technologies $-\mathbf{2 0 2 0}$}

problem and ensures the convergence of the corresponding algorithm for its solving. Thus, in particular, to find the distribution of the concentration of ferrous iron in a bioreactor by the method of characteristics, we solve a first order linear inhomogeneous partial differential equation. The corresponding solution will look like:

$$
\begin{aligned}
& F_{n}(x, t)=\left[\begin{array}{l}
\int_{0}^{x} \frac{F g_{n}\left(\tilde{x}, \sigma_{n} f(\tilde{x})-\sigma_{n} f(x)+t\right)}{\mathrm{v}(\tilde{x})} \mathrm{d} \tilde{x}+ \\
+F_{*}\left(t-\sigma_{n} f(x)\right), t \geq \sigma_{n} f(x), \\
\frac{1}{\sigma_{n}} \int_{n \Delta t}^{t} F g_{n}\left(f^{-1}\left(\frac{\sigma_{n} f(x)-t+\tilde{t}}{\sigma_{n}}\right), \tilde{t}\right) \mathrm{d} \tilde{t}+ \\
+F_{*}^{*}\left(f^{-1}\left(\frac{\sigma_{n} f(x)-t}{\sigma_{n}}\right)\right), t<\sigma_{n} f(x),
\end{array}\right. \\
& F g_{n}(x, t)=-\beta_{n} W_{n-1}\left(x-f^{-1}(\Delta t), t\right) \mathrm{B}_{n-1}\left(x-f^{-1}(\Delta t), t-\Delta t\right)- \\
& -\beta_{2} W_{n-1}\left(x-f^{-1}(\Delta t), t\right) U_{n-1}\left(x-f^{-1}(\Delta t), t-\Delta t\right) .
\end{aligned}
$$

In the paper multicomponent mathematical model of the process of groundwater purification from iron compounds using bacteria of the genus Gallionella and Leptothrix has been developed, an algorithm for solving the problem has been built. Based on the results of computer experiments, the time of effective operation of the bioreactor between washes (up to 9-10 days) was established, as well as the distribution of concentrations of all major components of the process in the middle of the contact load of the bioreactor was determined.

\section{REFERENCES}

[1] Zhurba M.G., Govorova Zh.M. (2008). Vodosnabzhenie. Uluchshenie kachestva vodyi: uchebnik dlya vuzov. Tom 2 . - M.: Izdatelstvo ASV. S.544.

[2] Mouchet, P. (1995). Biological Filtration for Iron and Manganese Removal: Some Case Studies. WQTC 95 (AWWA, New Orleans LA), Nov. P. 12-16.

[3] Kvartenko O. M. (2016). Vikoristannya biohimichnogo metodu v suchasnih tehnologiyah vodoochischennya pidzemnih vod (oglyad). Voda i vodoochisni tehnologiYi. Naukovo-tehnichni visti, №2(19). S. 51-65.

[4] Scholl M. A, Harvey R. W. (1992). Laboratory investigations on the role of sediment surface and groundwater chemistry in transport of bacteria through a contaminated sandy aquifer. Environmental Science \& Technology. Vol. 26. No.7. P.1410 - 1417

[5] Sharma, S.K., Petrusevski, B., Schippers, J.C. (2005). Biological iron removal from groundwater: a review. J. Water Supply Res. Technol. AQUA, 54. P. 239-247.

[6] Beek, C.G.E.M., van, Dusseldorp, J., Joris, K., Huysman, K., Leijssen, H., Schoonenberg Kegel, F., de Vet, W.W.J.M., van de Wetering, S., Hofs, B. (2015). Contributions of homogeneous, heterogeneous and biological iron (II) oxidation in aeration and rapid sand filtration (RSF) in field sites. J. Water SRT d AQUA, 65 (3). P.195-207.

[7] Stum, W., and Lee, G. F. (1961). Oxygenation of ferrous iron, Industrial Eng. Chem. 53, 143-146.
[8] Olsen, L.L., Twardowski, C.J.Jr. (1975). FeCO3 Vs $\mathrm{Fe}(\mathrm{OH}) 3$ precipitation in water-treatment plants. journal of American water works Association, 67(3): p. 150-153.

[9] Tamura, H., Goto, K., and Nagayama, M. (1976). The effect of ferric hydroxide on the oxygenation of ferrous ions in neutral solutions, Corrosion science, 16, 197-297.

[10] Stankevičius V.I. (1978). De-ironing of water by filtration. Moskalas Publishing House Vilnius.

[11] Oleynik A.Ya., Semenko G.I. (1997). Matematicheskoe modelirovanie protsessa udaleniya zheleza iz prirodnyih vod filtrovaniem. Himiya i tehnologiya vodyi, t. 19, № 5. S. 451-457.

[12] Kiselev Sergey Konstantinovich. (2000). Modelling and calculations of water deferrization at treatment filters considering changing hydraulic properties of loading. Thesis for academic degree of candidate. of techn. sc. 05.23.04 (Kiev national university of building and architecture. - K., 161

[13] Vries, D., Bertelkamp, C., Schoonenberg Kegel, F., Hofs, B., Dusseldorp, J., Bruins, J.H., de Vet, W, van den Akker, B (2017). Iron and manganese removal: Recent advances in modelling treatment efficiency by rapid sand filtration. Water Research, 109. P. 35-45.

[14] Oliynik O. Ya., Sadchikov O. O. (2013). Teoretichni doslidzhennya znezaliznennya vodi na dvosharovih filtrah. Probl. vodopostachannya, vodovidvedennya ta gidravliki. - KiYiv: KNUBA. Vip. 21. S. 14-22.

[15] Polyakov V.L., Martinov S.Yu. (2017). Do teoriyi flziko-himichnogo znezaliznennya pIdzemnih vod ta YiYi Informatsiynogo zabezpechennya. Chista voda. FundamentalnI, praktichni ta promislovi aspekti. Material V MizhnarodnoYi naukovo-praktichnoYi konferentsiYi. KiYiv, S. 178181

[16] Zevi Y., Dewita S., Aghasa A., Dwinandha D. Removal of Iron and Manganese from Natural Groundwater by Continuous Reactor Using Activated and Natural Mordenite Mineral Adsorption// International IOP Conf. Ser.: Earth Environ. Sci. 2018. 111 012016. P. 1-7.

[17] Tekerlekopoulou A.G., Vasiliadou I.A., Vayenas D.V. Physico-chemica and biological iron removal from potable water//Biochemical Engineering Journal. 2006. №31. P.74-83.

[18] Kvartenko O., Prisyazhnyuk I. (2017). Modelyuvannya kinetiki protsesu vidalennya spoluk zallza v bioreaktori. Tehnichni nauki ta tehnologiYi: naukoviy zhurnal. ChernIgIv: ChNTU. №4 (10). S. 247-254.

[19] Nikoladze G.I. (1978). Iron removal of natural and circulating waters. Moscow: Stroyizdat, $160 \mathrm{p}$.

[20] Mouchet, P. From Conventional to Biological Removal of Iron and Manganese in France/ P. Mouchet,// Journal of the American Water Works Association. - 1992 - vol. 84, no 4, p. 158-167.

[21] Hallbeck L., Pedersen K. (1990). Culture parameters regulating stalk formation and growth rate of Gallionella ferruginea. Journal of General Microbiology 136, 1675-1 680.

[22] Chana Clara, S., Fakra Sirine, C., Edwards, D., Emerson, D.C., Banfield, J. F.(2009). Iron oxyhydroxide mineralization on microbial extracellular polysaccharides. Geochimica et Cosmochimica Acta, 73. P. 3807-3818.

[23] Emerson, D., Field, E., Chertkov, O., Davenport, K.W., Goodwin, L., Munk, C., Nolan, M., Woyke, T. (2013). Comparative genomics of freshwater Fe-oxidizing bacteria: implications for physiology, ecology, and systematics. Frontiers in Microbiology / Evolutionary and Genomic Microbiology. Volume 4 | Article 254. doi: 10.3389/fmicb.2013.00254.

[24] Kvartenko A. Prediction of the process of biological deferrization of underground water in a bioreactor/ Aleksandr Kvartenko, Ihor Prysiazhniuk// Eastern-European Journal of Enterprise Technologies 2019, Volume 5, No. 10 (101) pp.14-22. DOI: 10.15587/17294061.2019.177537 